ЕКСПЕРИМЕНТАЛЬНА ТА КЛІНІЧНА ФАРМАКОЛОГІЯ

Recommended by Doctor of Medicine, professor V.A.Volkovoy

UDC 615.454.1: 616-001.4:-001.17: 616-003.9: 616-612.398.193: 08: 665.327.2 |.3

\title{
THE STUDY OF TOXICOLOGICAL PROPERTIES OF A NEW COMBINED CREAM "DERMALIPOIN"
}

\author{
A.M.Sheyhali, N.M.Kononenko \\ National University of Pharmacy \\ Key words: toxicological properties; combined cream "Dermalipoin"
}

The aim of the work was to study acute toxicity, the irritating and allergic effects of a new combined cream "Dermalipoin" consisting of a-lipoic acid, urea, olive oil, tea tree oil, PEG-400. It has been found that the $L D_{50}$ of the cream with intragastric introduction is greater than $5000 \mathrm{mg} / \mathrm{kg}$, and when applied to the skin $L D_{50}>2810 \mathrm{mg} / \mathrm{kg}$; in accordance with the classification of K.K. Sidorov it allows to refer this cream to the class of almost nontoxic substances (the V-th toxicity class). "Dermalipoin" cream shows no irritative action in contact with the mucous membrane of the eye and sensitizing actions in external application.

Treatment of wounds remains one of the most important problems of modern medicine [13]. The analysis conducted has shown that at the pharmaceutical market out of 12 medicines intended for the I-st phase of the wound process only one combined drug - "Inflarax" ointment ("Zdorovya", Ukraine) has a multidirectional and pronounced pharmacological action [3]. But one drug cannot completely satisfy the needs of the treatment of purulent wounds, therefore, there is the necessity of development and introduction of new medicines with a wide range of the pharmacological action.

Nowadays one of the most promising soft medical forms are creams as they more fully and smoothly release the medicinal substances, they are easily applied and absorbed by the skin, they do not leave on it greasy luster, they are economically available, etc. [5].

At the National University of Pharmacy (NUPh) a new combined product in the form of a cream has been developed for treating inflammatory and microbial skin diseases conventionally named "Dermalipoin" containing $\alpha$-lipoic acid, urea, olive oil, tea tree oil, PEG-400 (polyethylene glycol). PEG-400 is a solvent with a pronounced osmotic activity, which causes its wide application in the production of creams for the treatment of infected wounds where it provides the osmotic and dehydration effects, which accelerates the term of wound healing [12]. Medicines containing PEG have high efficiency, especially in the treatment of exudative dermatoses when fat and carbohydrate carriers can not be used [1]. PEG well dissolves a great number of medicinal substances, easily release them providing a good contact with the skin or the wound surface tissue, which, in turn, significantly increases their absorption and activity [7].

One of the main stages of introduction of medicines is to determine their toxicity [2]. The study of acute toxicity along with other indicators (possible local irrita- tive and allergic effects) that characterize the toxicological properties of medicinal products is a mandatory requirement of the State Pharmacological Centre (SPhC) of the Ministry of Public Health of Ukraine in preclinical study of new medicines [7].

The aim of the work was to study acute toxicity, the irritating and allergic effects of a new combined cream "Dermalipoin".

\section{Materials and Methods}

Preclinical study of toxicological properties of "Dermalipoin" cream was conducted at the premises of the Central Scientific Research Laboratory of the NUPh. In preclinical studies the experimental animals grown in vivarium of the Central Research Laboratory equipped according to the sanitary-and-hygienic norms were used. All animals were kept under the standard sanitary conditions [8]. During the experiment the animals were kept in vivarium at $19-24^{\circ} \mathrm{C}$, with humidity of not more than $50 \%$, with the natural light mode "day-night" in plastic cages on a balanced food diet. Before the experiment the animals acclimatized themselves under experimental room conditions within 7 days. The experiments were carried out in accordance with the national "General ethical principles of experiments on animals" (Ukraine, 2001), which are consistent with the provisions of the European Convention for the Protection of Vertebrate Animals used for Experimental and Other Scientific Purposes (Strasbourg, 18.03.86).

Acute toxicity of the cream was studied according to Pastushenko G.V. method in nonlinear sexually mature male white mice with the body weight of $18-25 \mathrm{~g}$ and in nonlinear sexually mature male white rats with the body weight of 180-200 $\mathrm{g}$ in a single intragastric introduction and skin application. Toxicity was assessed according to the generally accepted classification of K.K.Sidorov [10]. When studying acute toxicity of drugs 
Table 1

Table 2

The study of acute toxicity of "Dermalipoin" cream in mice in intragastric introduction $(n=6)$

\begin{tabular}{|c|c|c|}
\hline Group & Dose, $\mathrm{mg} / \mathrm{kg}$ & $\begin{array}{c}\text { Animals that died/ } \\
\text { the total number of animals }\end{array}$ \\
\hline 1 & 500 & $0 / 6$ \\
\hline 2 & 1000 & $0 / 6$ \\
\hline 3 & 3000 & $0 / 6$ \\
\hline 4 & 4000 & $0 / 6$ \\
\hline 5 & 5000 & $0 / 6$ \\
\hline
\end{tabular}

the survival/mortality of animals is an integral indicator, which allows calculating the drug medium lethal dose $\left(\mathrm{LD}_{50}\right)$. It is recommended to use 5 levels of doses. When it is impossible to introduce the drug in doses that cause death of animals, then in order to study acute toxicity the SPhC of the Ministry of Public Health of Ukraine recommends to use the maximal dose of the IV-th toxicity class (low toxic substances) taking into account the way of introduction [2]. Therefore, when determining nontoxicity of the cream in the dose of $2810 \mathrm{mg} / \mathrm{kg}$ in application on the skin and in the dose of $5000 \mathrm{mg} / \mathrm{kg}$ in intragastric introduction the further research may be considered inexpedient. In accordance with the recommendations of the SPhC of the Ministry of Public Health of Ukraine the number of animals was 6 in each experimental group [2]. Acute toxicity of the experimental samples was studied when applying the cream on a skin area of the back previously clipped, which was not less than $10 \%$ of the total surface area of the animal. Test samples were applied with a thin layer in the dose of $2810 \mathrm{mg} / \mathrm{kg}$. The monitoring of survival, clinical signs and condition of the skin (with the skin application) was carried out within 14 days.

The local irritative effect was studied in guinea pigs with the body weight of 400-450 g using the conjunctival test [9]. For this purpose the cream was introduced into the conjuctival ocular vesicle of the right eye of the experimental animals. The left eye served as the control. The reaction of the mucous membranes of the eye was observed in $15 \mathrm{~min}$, one hour and a day after introduction of the cream. In the experiment the degree of hyperemia, swelling and the amount of discharge were considered. Assessment of the damaging effect was conducted by the rating scale:

0 - the absence of the response of the mucous membrane of the eye;

1 - a slight redness of the lacrimal ducts;

2 - the redness of the lacrimal ducts and the sclera in the cornea;

3 - the redness throughout the conjunctiva and sclera.

The study of the possible allergic effect of the cream was performed using the method of skin applications $[6,11]$. Experiments were conducted in guinea pigs with the body weight of 400-450 g. The experimental animals were divided into 2 groups: the first group was the control, in the animals of the second group cream was applied on the skin daily in the dose of $0.01 \mathrm{ml} / \mathrm{cm}^{2}$. The test was performed by applying the decoupling dose on the 10-th and the 20-th day of each sensibilization. In the case of the absence of sensibilization signs at the
The study of acute toxicity of "Dermalipoin" cream in rats after application on the skin $(n=6)$

\begin{tabular}{|c|c|c|c|c|}
\hline $\begin{array}{c}\text { The drug } \\
\text { under study }\end{array}$ & $\begin{array}{c}\text { Dose, } \\
\mathrm{mg} / \mathrm{kg}\end{array}$ & Died & Survived & $\begin{array}{c}\text { The reaction } \\
\text { of the skin }\end{array}$ \\
\hline $\begin{array}{c}\text { "Dermalipoin" } \\
\text { cream }\end{array}$ & 2810 & 0 & 6 & $\begin{array}{c}\text { without } \\
\text { changes }\end{array}$ \\
\hline
\end{tabular}

Table 3

The effect of "Dermalipoin" cream on the condition of the skin cover of guinea pigs $(n=6)$

\begin{tabular}{|l|c|c|c|}
\hline \multirow{2}{*}{$\begin{array}{c}\text { Conditions } \\
\text { of the } \\
\text { experiment }\end{array}$} & \multicolumn{3}{|c|}{ The thickness of skin folds, $\mathrm{mm}$} \\
\cline { 2 - 4 } & \multicolumn{3}{|c|}{ The time frame of the study } \\
\cline { 2 - 4 } Control & $3.2 \pm 0.2$ & $3.0 \pm 0.1$ & $3.1 \pm 0.14$ \\
\hline $\begin{array}{l}\text { "Dermalipoin" } \\
\text { cream }\end{array}$ & $3.0 \pm 0.1$ & $3.1 \pm 0.2$ & $3.0 \pm 0.15$ \\
\hline
\end{tabular}

1-st phase the application of the cream under research was continued to the 2-nd phase. On the 20-th day the test was repeated. The skin condition was assessed in 1 hour and 24 hours after applying the decoupling dose and the changes were reflected by the rating scale: 1 pointpunctate weak hyperemia; 2 points - punctate intense hyperemia; 3 points - continuous weak hyperemia; 4 points continuous intense hyperemia and infiltration hyperemia. In order to evaluate the expression of inflammation after application of the decoupling dose the thickness of skin folds was measured.

The data obtained was processed by the method of variation statistics at the significance level $\mathrm{p}<0.05$ (taking into account the arithmetic mean and its standard error) [4].

\section{Results and Discussion}

As mentioned, the integral indicator in the study of acute toxicity of drugs is the survival/mortality of animals, it allows to calculate the medium lethal dose (LD $)$ that is the main toxicological characteristics of a medicine. The research results are presented in Tab. 1, they indicate the absence of animals' deaths in a single intragastric introduction of the cream in all doses.

Thus, $\mathrm{LD}_{50}$ of the cream analyzed lies outside the IV-th class of toxicity $\left(\mathrm{LD}_{50}>5000 \mathrm{mg} / \mathrm{kg}\right.$ ). It allows to refer this cream to the class of practically nontoxic substances (the V-th toxicity class) according to K.K.Sidorov classification.

Since "Dermalipoin" cream is offered as a potential drug for topical treatment of skin lesions, it was necessary to study its possible negative effects on the body of experimental animals in a single skin application.

The results of the experimental studies are pesented in Tab. 2 and indicate the absence of toxic effects in the maximal dose $(2810 \mathrm{mg} / \mathrm{kg})$.

When studying the possible local irritative effect it was found that introduction of the cream into the conjuctival ocular vesicle of the experimental animals caused a slight redness during the first 5-8 min, but in $15 \mathrm{~min}$ any noticeable reaction in the mucous membrane of the eye was not observed.

Analysis of the results of the experiment conducted allows to draw a conclusion about the absence of the ir- 
ritative action of the cream in contact with the mucous membrane of the eye.

The results of the study of possible allergic effects of the cream are given in Tab. 3. On the 10-th day the signs of sensibilization were not detected. When applying the cream within 20 days any notable changes from the skin cover was not observed. Application of the decoupling dose of the cream did not lead to development of hyperemia, infiltration and edema. The thickness of skin folds after application of the decoupling dose did not change in relation to the control.
CONCLUSIONS

1. It has been found that the $\mathrm{LD}_{50}$ of the cream with intragastric introduction is greater than $5000 \mathrm{mg} / \mathrm{kg}$, and when applied to the skin $\mathrm{LD}_{50}>2810 \mathrm{mg} / \mathrm{kg}$; in accordance with the classification of K.K. Sidorov it allows to refer this cream to the class of almost nontoxic substances (the V-th toxicity class).

2. "Dermalipoin" cream shows no irritative action in contact with the mucous membrane of the eye and sensitizing actions when applying on the skin.

\section{REFERENCES}

1. Блатун Л.А. // Хирургия. - 2011. - №4. - С. 51-59.

2. Коваленко В.М., Стефанов О.В., Максимов О.В. та ін. Експериментальне вивчення токсичної дї̈ потениійних лікарських засобів. У кн.: Доклінічні дослідження лікарських засобів: Метод. рекоменд. / 3 а ред. чл.-кор. НАМН Украӥни О.В.Стефанова. - К.: Авіценна, 2001. - С. 74-97.

3. Компендиум 2008 -лекарственные препараты / Под ред. В.Н.Коваленко, А.П.Викторова. - К.: МОРИОН, 2008. - 2120 c.

4. Лапач С.Н., Чубенко А.В., Бабич П.Н. Статистические методы в медико-биологических исследованиях с использованием Excel. - К.: МОРИОН, 2000. - 320 c.

5. Луичевич О.Э., Тамразова О.Б., Шикунова А.Ю. // Хирургия. - 2011. - №5. - С. 72-77.

6. Методи клінічних та експериментальних досліджень у медиџині / Л.В.Беркало, О.В.Бобович, Н.О.Боброва та ін. За ред. І.П.Кайдашева. - Полтава, 2003. - 320 с.

7. Надлежащуая производственная практика лекарственных средств / Под ред. Н.А.Ляпунова, В.А.Загория, В.П.Георгиевского, Е.П.Безуглой. - К.: МОРИОН, 1999. - С. 508-545.

8. Науково-практичні рекомендації з утримання лабораторних тварин та роботи з ними / Ю.М.Кожемякін, О.С.Хромов, М.О.Філоненко, Г.А.Сайфетдінова. - К.: Авіценна, 2002. - 156 с.

9. Сернов Л.Н., Гацура В.В. Элементы экспериментальной фармакологии. - М.: Всерос. науч. иентр по безопасности биологически активных вещзеств, 2000. - 352 с.

10. Сидоров К.К. // Токсикол. новых пром. хим. веществ. - 1973. - №13. - С. 47-51.

11. Яковлєва Л.В., Ткачова О.В., Бутко Я.О., Лар'яновська Ю.Б. Експериментальне вивчення нових препаратів для місиевого лікування ран: Метод. рекоменд. - Х.: Вид-во НФаУ, 2013. - 52 с.

12. Atiyeh B.S., Dibo S.A., Hayek S.N. // Int. Wound J. - 2009. - №6. - P. 420-430.

13. Mumcuoğlu K.Y., Ozkan A.T. // Turkiye Parazitol. Derg. - 2009. - №33. - P. 307-315.

\section{ДОСЛІДЖЕННЯ ТОКСИКОЛОГІЧНИХ ВЛАСТИВОСТЕЙ НОВОГО КОМБНОВАНОГО КРЕМУ «ДЕРМАЛІПОїН» \\ А.М.Шейхалі, Н.М.Кононенко \\ Ключові слова: токсикологічні властивості; комбінований крем «Дермаліпоїн»}

Досліджена гостра токсичність, місцевоподразнювальна та алергізуюча дія нового комбінованого крему «Дермаліпоїн», до складу якого увійшли: $\alpha$-ліпоєва кислота, сечовина, оливова олія, олія чайного дерева, ПЕГ-400. Встановлено, що LD введенні перевищує 5000 мг/ке, при нанесенні на шкіру ${ }^{50} L D>2810$ мг/кг, що дозволяє віднести його у відповідності до класифікації К.К.Сидорова до класу практично нетоксичних речовин (V клас токсичності). Крем «Дермаліпоїн» не виявляє іритативної дії при контакті зі слизовою оболонкою ока та не чинить сенсибілізуючої дії при нашкірному нанесенні.

\section{ИССЛЕДОВАНИЕ ТОКСИКОЛОГИЧЕСКИХ СВОЙСТВ НОВОГО КОМБИНИРОВАННОГО КРЕМА «ДЕРМАЛИПОИН» \\ А.М.Шейхали, Н.Н.Кононенко \\ Ключевые слова: токсикологические свойства; комбинированный крем «Дермалипоин»} Изучена острая токсичность, местнораздражающее и аллергизирующее действие нового комбинированного крема «Дермалипоин», в состав которого вошли: $\alpha$-липоевая кислота, мочевина, оливковое масло, масло чайного дерева, ПЭГ-400. Установлено, что LD внутрижелудочном введении превышает 5000 мг/ке, при нанесении на кожу - LD $>2810$ мг/ке, что позволяет отнести его в соответствии с классификацией К.К.Сидорова к классу практически нетоксичных веществ (V класс токсичности). Крем «Дермалипоин» не проявляет ирритативного действия при контакте со слизистой оболочкой глаза и не оказывает сенсибилизирующего действия при наружном нанесении. 